\title{
Connecting the dots: toward a networked framework to conceptualizing identity in mathematics education
}

\author{
Olga O. Fellus ${ }^{1}$ (i)
}

Accepted: 18 April 2019 / Published online: 29 April 2019

(c) The Author(s) 2019

\begin{abstract}
The construct of identity is increasingly recognized as a dominant and determining aspect in learning mathematics. While researchers-collectively - theorize identity as situated and negotiated, they also draw attention to the unwieldy nature of the concept that makes it difficult to define and operationalize. The purpose of this paper is to contribute to the conversation on identity in mathematics education by providing a literature review through the lens of a four-part networked identity model configured by Ivanič (1998) in the field of academic writing. Following a short introduction of the meaning of identity as a research construct, the paper discusses Ivanič's four identity-related aspects that include autobiographical identity, discoursal identity, authorial identity, and socioculturally available identities. It then examines research in K-12 mathematics education that focuses on learners' identity through the perspective of Ivanič's model to suggest an instrumental, yet tentative, multidimensional framework for exploring identity in mathematics education. The paper concludes with potential trajectories for future research.
\end{abstract}

Keywords Networked identity theory · Autobiographical identity $\cdot$ Discoursal identity $\cdot$ Authorial identity $\cdot$ Socioculturally available identities $\cdot$ Learner identity $\cdot$ Mathematics education

\section{A shift in epistemologies}

In order to understand the emergence of identity as a research construct within mathematics education, I begin with a short, and by no means comprehensive, overview of the development of identity as a research construct. Historically speaking, following social, national, and political turmoil in the 1960s, talk about identity became popularized and has led to the distinction between perceiving identity as a product versus conceptualizing it as a process. Harré and Gillett (1994) refer to this as a shift in theory pointing to "the difference between the old idea of the self as something inside a person and the new idea of the self as a continuous production" (p. 110). This shift in theory is also noted by Polkinghorne (1988) who underscores the difference in perceiving identity as something static to understanding it as something dynamic. Specifically, he distinguishes between identity as "a flattened reality that

Olga O. Fellus

osnat.fellus@uottawa.ca

1 University of Ottawa, Ottawa, Canada consists of physical objects in time and space along with their relations" (p. 149) and identity as a "construction built on other people's responses and attitude toward a person and is subject to change as these responses, inherently variable and inconsistent, change in their character" (p. 145).

Another layer that underscores the difference in perspectives lies in the etymology of the word identity, which offers the meanings of sameness (idem identity) and selfhood (ipse identity) (Ricoeur 1992). The former implies a sense of constant sameness to similar others, the latter of continual development of one's sense of self; the former elides individuals to create a unified façade, the latter brings forth the diversity between individuals; the former is oriented toward the past, the latter toward the possible future (Fellus 2018; Fellus and Biton 2017). Conceptualizing identity as idem identity-mostly a substance that a person possesses-is qualitatively different than perceiving it as ipse identity-an idea to be continually constructed.

This distinction between idem and ipse identity is instrumental in tracing a shift in epistemologies in conceptualizing identity. Whereas romanticism and modernism, for example, frame identity as what one should become, epistemologically treating identity within postmodernism shifts the focus 
of attention to how one can become (Gergen 1991). This is equivalent to understanding identity as forms of reproduction-i.e., looking back and making more of what is already known-and production-i.e., leading forward and making something that was not there before (see Klein 1967, "production," p. 1248).

When speaking of identity as a process that is epistemologically understood within postmodernism, one may wonder about the ontology of identity. In other words, what is the entity of identity? What is it that we do when we engage in identity work? Ontologically speaking, in the context of mathematics education, identity is understood as stories of diverse sources, functions, and structures that are related to mathematics and to learning mathematics (see Fellus and Glanfield 2019; Sfard and Prusak 2005). Against this background of postmodernism and the ontological entity of identity work, I turn the limelight to those not-yet-sufficiently-explored research areas of ipse identity within K-12 mathematics education.

\section{Toward a networked model for understanding identity}

Research that explores identity as a process can be seen in studies in mathematics education that focus on, among other things, the relationship between learners' identity and pedagogical practices (e.g., Boaler et al. 2000), learners' identity and their sociocultural backgrounds (e.g., Sfard and Prusak 2005), learners' identity and institutionally assigned groups (Oakes 1990), and learners' identity and their imagined futures (e.g., Black et al. 2010). However, questions still remain concerning identity-related, significant, and networked storylines that continually construct one's mathematical identity in a complex, nonlinear, and dynamic way. Research in mathematics education uses different foci of attention to point to two important insights: a) that learners' mathematical identity is multifarious, and b) that learners' mathematical identity is co-constructed in and through language and other semiotic artefacts. Understanding identity epistemologically within postmodernism that sheds light onto how one can become (see Gergen 1991, pp. 245-247), and ontologically as "reified, significant, and endorsable stories" (Sfard and Prusak 2005) is conducive to exploring identity through a multidimensional and multidirectional theoretical framework. I import such a framework from the field of academic writing where Roz Ivanič (1998) has crafted a four-part model to better understand the development of writer identity among eight mature university students, who were the first in their families to enter postsecondary education and expressed a need to improve their academic writing.
Ivanič (1998) argues that the act of writing is also an act of identity construction "in which people align themselves with socio-culturally shaped possibilities for self-hood, playing their part in reproducing or challenging dominant practices and discourses, and the values, beliefs and interests which they embody" (p. 32). She then succinctly describes the intertwined elements of this argument, which include the following:

What people do conveys a message about their identity; Writing is a particularly salient form of social action for the negotiation of identities; [T] here is no such thing as 'impersonal writing'; The relations of power, interests, values, beliefs and practices in institutional settings enable and constrain people's possibilities for self-hood as they write; Some discourses are more powerful, and/or more highly valued than others, and people are under pressure to participate in them through adopting them in their writing; Writers bring their 'autobiographical self' to an act of writing. This is shaped by their life-histories and the social groups with which they identify; A writer's autobiographical self influences the discoursal self they construct for themselves in a specific piece of writing, and leads them to own or disown aspects of it; When people enter what is for them a new social context such as higher education, they are likely to find that its discourses and practices support identities which differ from those they bring with them. (pp. 32-33)

Recognizing these elements that bond writing and identity, can potentially liberate both students and instructors "as [instructors] write and help students to write in institutional settings" (p. 34). Exploring the notion of identity in academic writing, Ivanič considers the students she worked with not as a group but rather as eight separate case studies. This approach, she suggests, allows the researcher to focus on the nature of writer identity rather than on the nature of the group as a whole (p. 113)-thus demonstrating the compatibility of the model Ivanič offers with the exploration of ipse identity rather than idem identity.

Collecting data from the students in the form of conversations about the role of literacy in their lives, past and present, was accompanied by working with the students as coresearchers and engaging in ongoing analyses of their essays, their approach to writing tasks, their practices, their voices in the text, and the use of direct quotations and of words that "seemed to be "coming from somewhere"" (p. 115). Following the submission of the essays, the students' tutors were interviewed to obtain their views "on what the essay contributed to their impression of the writer" (p. 116). Ivanič's analysis of the data gradually revealed the complexities of the interwoven relationships among the four identity-related aspects "each contributing a different perspective" (p. 169). 
In other words, Ivanič's (1998) work demonstrates how the students' development of their academic writing skills is coconstructed through their past experiences of formal learning and writing, the way they identify themselves by address and attribution as learners and writers of academic texts, how they appropriate notions and ideas and make them their own, and how they build their identities by choosing with whom to align their writing style from available possibilities. The usefulness of Ivanič's (1998) theoretical framework for understanding identity is rooted in its highlighting the interconnectedness between multiple dimensions in constructing one's identity. It reminds us that although we may explore one identity-related dimension at a time, no dimension operates in isolation from the other dimensions.

Rereading the blocked quotation cited above, this time changing the words 'writing' and 'write' with 'doing mathematics,' and the words 'a writer' and 'writers' with 'K-12 students,' most readers may probably see the applicability of this argument to the context of mathematics education. To wit, in doing mathematics, identity plays a crucial role, there is no such thing as impersonal mathematics, and learners of mathematics bring their past experiences to a mathematicsrelated act. In understanding identity as a multifarious construct, we can more carefully attend to the question: How is a learner's mathematical identity co-constructed through simultaneously operating networked dimensions? Importing Ivanič's framework into mathematics education, I embarked on a theory-driven overview of K-12 research on identity in mathematics education through the lens of Ivanič's fourpart model. I formulated the following questions to guide my reading of research on identity within mathematics education: How do past mathematics-related experiences mould one's perception of self as a learner of mathematics? How are individuals' mathematics identities co-constructed through the way they are talked to and about as learners and doers of mathematics? How do individuals develop ownership over ideas and concepts in and about mathematics through processes of appropriation? And, how do individuals recruit or reject socioculturally available mathematical identities?

Answers to these questions lie in a growing number of studies on identity within mathematics education. In fact, in the last two decades, research has taken multiple, seemingly unrelated, points of foci (Darragh 2016; Radovic et al. 2018). Recent reviews of the research literature on identity in mathematics education (Darragh 2016; Radovic et al. 2018) inductively categorize existing research into five groups: participative, narrative, discursive, psychoanalytic, and performative (Darragh 2016), and into three two-pole dimensions that include a subjective/social dimension, a representational/enacted dimension and a change/stability dimension (Radovic et al. 2018). These review studies are inductive in the sense that they carefully categorize the characteristics of identity work as they were researched within mathematics education. What seems to be missing, though, is a unifying theory that highlights the compatibility among the different identity nodes. Understanding identity epistemologically within postmodernism and ontologically as storylines, this paper looks into K-12 research on identity in mathematics education through the lens of one such theory to suggest an operationalization of distinct, yet inseparable identity dimensions that include one's mathematics autobiographical identity, mathematics discoursal identity, mathematics authorial identity, and socioculturally available mathematics identities.

In order to conduct the theory-driven review, I formulated four inclusion criteria for studies to be included in my overview of K-12 research on identity: (1) that the focus of the study was within K-12 grade levels; (2) that the focus of the study was learners' identity in mathematics; (3) that the study used empirical data operationalizing identity; and (4) that the study was published in an English peer-reviewed publication. The rationale behind the search for research on K-12 students was to focus on mathematics identity research done on the very population that is the object of public education.

Using the advanced-search feature in Google Scholar and Web of Science, I searched for empirical studies on $\mathrm{K}-12$ mathematics identity published in peer-reviewed journals without specifying years of publication to leave the search as open as possible. I used different combinations of the following search terms occurring in the title of the article: identit*, math*, elementary, secondary, high school, experience*, stor*, autobiograph*, ownership, discourse, movies, and films. Collectively, these initial searches yielded 99 publications on Google Scholar and 218 in the Web of Science. However, going through the titles of the listed works and type of publication, and reading the abstracts of some that did not clearly specify who were the participants in their research, the number of references that matched the inclusion criteria was winnowed down to 34 studies as the great majority of the papers included teachers as participants. Dissertations, books, and conference proceedings were removed as well. Using the snowball technique by scrutinizing the references of the 34 studies, I identified 11 more studies that matched the criteria thus increasing the pool of selected studies to 45 . At the conclusion of the process, every study was analyzed through the lens of Ivanič's (1998) four identity-related dimensions.

Following the theory-driven analysis of the studies, each was categorized into one of the four dimensions. The decision where to place each study was based on considerations of which identity aspect was most prevalent in the particular study. The following sections describe each dimension, provide theoretical background to buttress the underpinning of 
each dimension, and discuss examples from relevant studies on K-12 mathematics identity.

\subsection{Autobiographical identity}

Learners' experiences and their interpretation of these experiences shape their behaviours, attitudes, and beliefs about mathematics (see Di Martino and Zan 2010; Lange and Meaney 2011; Towers et al. 2018). The importance of storied selfhoods, argue linguistic anthropologists Ochs and Capps (1996), is grounded in their power to "situate particular events against a larger horizon of what we consider to be human passions, virtues, philosophies, actions, and relationships" (p. 30). Similarly, psychologists, McAdams and Olson (2010) contend, "Narrative identity is the storied understanding that a person develops regarding how he or she came to be and where he or she is going in life" (p. 527). Within mathematics education, autobiographical research points to relationships with socioculturally solidified beliefs about who can and cannot do mathematics (see Berry et al. 2011), identification of self as a learner of mathematics (see Di Martino and Zan 2010), increased participation and ownership over mathematical ideas (Graven and Buytenhuys 2010), and beliefs that mathematics is not fun and is all about hard work and manipulating numbers and operations (Towers et al. 2018).

Looking into studies that elicited autobiographical stories of learners' experiences with mathematics, Towers et al. (2016), found that whereas research on teachers' autobiographical mathematics identity has been extensive in scope and method, comparable research among K-12 students has remained scant. The common thread running through these studies is the link between the experiences learners co-construct and share and other identity-related dimensions such as socioculturally available beliefs about mathematics and learning mathematics, and identification of self and others as competent or incompetent in learning and doing mathematics.

These relationships are instructive in the sense that they position mathematical autobiographies as a useful tool not only to learn about learners' diverse experiences but also to identify ways of intervention. The four K-12 studies on mathematics autobiographical identity that are cited below demonstrate how past experiences shape learners' attitude toward school mathematics. Berry et al. (2011) asked 32 Black boys in Grades 5-7, who participated in a mathematics camp and who were positioned as good in mathematics, to write their mathematical autobiography. The researchers show how these children draw on socioculturally available selfhoods of Black students being good in mathematics to continue investing in their learning of mathematics through acts of identifying themselves and being identified by others as good in mathematics. In another study, Di Martino and Zan (2010) asked about 1600 students in Grades 1-13 to write anonymous essays titled "Me and maths: My relationship with mathematics up to now." These scholars identified three dimensions in autobiographical identity that demonstrate how learners' experiences with mathematics shape their attitude and emotional disposition toward mathematics, their perception of their competence as learners of mathematics, and their vision of mathematics. They also show how these three dimensions of mathematics-related autobiography are "strictly interconnected" (p. 43) and that each contains multiple profiles. Graven and Buytenhuys (2010) describe a case study of one cohort of Grade 10-to12 students who were engaged in journaling their experiences learning mathematics. The students, who initially defined themselves as mathematical failures, changed their mathematical identity through their teacher's deliberate and explicit demand that they take ownership over mathematical ideas through participation in discussions and sense making. In their research on autobiographical data elicited through drawings and interviews with four- to nine-year olds, Towers et al. (2018) show how very young children have a very concrete perception of mathematics as something that is all about numbers and numerical operations; that is hard; that others are smart in; and that is not fun to do.

That K-12 research on autobiographical identity allows access to learners' developing identities as learners of mathematics renders it a construction site that calls for further attention, as it shows relationships with relevant constructs such as attitude toward mathematics and the possibilities of changing learning trajectories for learners of school mathematics.

\subsection{Discoursal identity}

Toward the end of the twentieth century, the idea that one's identity is framed through discourse was identified as a turning point in research and practice (Harré and Gillett 1994). Holland et al. (1998) suggest that one's identity is orchestrated through the way people speak of themselves and are spoken to by others (p. 178). Erdinast-Vulcan (2008) suggests that one's identity is constructed by selftalk: "We are, to put it briefly, 'authored,' configured by an internalized Other in much the same way as a hero is authored by the writer of fictional narratives" (p. 4). Ivanič (2006) locates the other in interlocutors and contends that identity is co-constructed by the way people are talked to and about. She brings the story of Logan to demonstrate that one's identity is constructed by address, i.e., how individuals are talked to by others; by attribution, i.e., how individuals are talked about by others; and by affiliation and alignment, i.e., how individuals sound like others. Because interaction is the main mode of teaching and learning (Vygotsky 1978), it is important to understand 
how learners' mathematical identity is co-constructed in and through interaction with self and others.

Given that identity is ontologically understood as stories, forms of address, attribution, and affiliation can be framed as storylines that people take on or that are assigned to people. Operationally speaking, these storylines can be identified through Sfard and Prusak's (2005) triple model for identity-related stories that "are reifying, endorsable, and significant" (Sfard and Prusak 2005, p. 16). These references can be represented by a configuration of $\mathrm{B}^{\mathrm{A}} \mathrm{C}$, when $\mathrm{A}$ is the object of the story told, $\mathrm{B}$ is the author of the story, and $\mathrm{C}$ is the recipient (Sfard and Prusak 2005, p. 17). This model provides a helpful, operational tool to explore discoursal identity that combines, at once, Ivanič's (2006) discoursal means of identity construction (i.e., address, attribution, and affiliation) and Erdinast-Vulcan's (2008) inclusion of an internalized Other.

Relevant work in K-12 mathematics education reveals how the way learners are talked to and about propagates and continually reproduces specific identities over others (see Hodgen and Marks 2009). Hogan (2008), for example, provides empirical support to demonstrate how students' academic achievements in mathematics are "less about [their] intrinsic abilities and more about how [they are] constructed as learners by [their] teacher" (p. 95). Here, too, how students are identified as mathematically competent or incompetent by self and others has been shown to be a determining aspect in one's identity as a learner of mathematics.

Mason and McFeetors (2007) interviewed 400 Grade-10 students over a full school year. They demonstrate through students' "narration about goals, actions, and decision making" (p. 294) how identity is strongly associated with students' course selection among four available levels of mathematics courses in Grade 10 (Honours, Pre-Calculus, Applied, or Consumer) and how the way students identify themselves as learners of mathematics informs their ongoing decision making. For example, being identified as smart in mathematics nullified the option of seeking help-students simply decided not to ask for help when they needed it because they feared that if they did, they would no longer be identified as smart in mathematics. Mason and McFeetors (2007) explain, "asking for help was a difficult identity matter for these students: They were in the academic mathematics courses precisely because they were smart kids, and (as they had experienced personally throughout their junior high years) smart kids do not need to ask for help" (p. 309). Mason and McFeetors also demonstrate how as a result of receiving lower grades in mathematics, students "had recalibrated their identities from previous years. They had lowered their expectations - of themselves, and of mathematics" (p. 310 ), thus indicating a strong association between the reified stories learners attribute to themselves and their mathematics-related choices and decision-making.

Studies that focus on how students are talked to and about as learners of mathematics emphasize an operationalization of identity as the reified mathematical storylines shared by and with learners through address and attribution. They also demonstrate how these storylines inform learners' mathematics-related choices and actions.

\subsection{Authorial identity}

According to Ivanič (1998), self as author references one's " "voice' in the sense of [one's] position, opinions, and beliefs" (p. 26). Students' authorial identity and the learning of mathematics may seem to some as an oxymoron. This perception cannot be further from the truth if we consider the act of authoring as the driving force behind doing real mathematics (see Feynman 1965). Interestingly, research shows that when students get a chance to practice freedom of thought as Feynman put it, they attain higher achievements in mathematics (see Mann 2006). Indeed, the National Council of Teachers of Mathematics (NCTM 2000), while not explicitly using the term authoring, lists expected authoring-related actions such as developing ideas, exploring phenomena, justifying results, and using mathematical conjectures (p. 56). Recent work has foregrounded taking ownership over meaning making of mathematical ideas as essential to developing an authorial identity (see Fellus and Biton 2018; Grant et al. 2015; Landers 2013; Langer-Osuna 2015, 2016, 2017, 2018).

Drawing on Bakhtin (1981), authorial identity in the context of mathematics education is understood here as instances when speakers populate mathematical concepts with their own accents and intentions. Opportunities for learners to develop their authorial identity in mathematics through processes of taking ownership over mathematical ideas have been identified as the very arenas where students construct their identities as learners of mathematics. Black (2009), for example, used audio and video data that she collected over a period of five months in one primary classroom where she also interviewed the students as well as their teacher. She looked into classroom interaction and demonstrated how patterns of participation divided the students into those whose contributions to whole-class discussions were productive and those whose contributions were nonproductive. She observed that students who had "freedom to develop [their mathematical] ideas" (p. 42) had more opportunities to negotiate shared meanings with the teacher. This is important if we consider the continual, and attended to, process of participation and making sense of mathematical ideas as the cornerstone in students developing their authorial identity. 
Indeed, Black (2009) observes, while students "who participated in mostly productive interactions displayed an increase in expertise and subsequent movement towards the centre of the social practice of the classroom, i.e., they moved towards identities of full participation" (p. 45), others "who experienced mostly non-productive talk appeared to be coping with their involuntary involvement in classroom discussions, but at the same time were not accessing situated meanings embedded within the practice of classroom mathematics, i.e., they moved towards identities of non-participation" (p. 45). Black (2009) categorized the students into four groups depending on the quantity and quality of their classroom interactions. She noticed that these patterns were informed by socioculturally available ways of being that the teacher fostered by the way she interacted with the students.

Similarly, findings and insights from studies such as Venkat and Graven (2008) as well as others (see McFeetors and Mason 2005; Silver 1997; Wirtz and Kahn 1982) suggest a strong relationship between opportunities to develop authorial identity in mathematics through increased forms of participation and sense making in and about mathematics, and through learners' appropriation of mathematical ideas. Learning in environments that allow and encourage overt processes of participation, sense making, and appropriation of mathematical ideas, students continually negotiate their "ability, facility, and legitimacy to contribute to, take responsibility for, and shape meanings that matter in a social configuration" (Wenger 1998, p. 197).

Most recently, Langer-Osuna's (2015, 2016, 2017, 2018) work has harnessed the construct of authorship to frame what students are expected to do in mathematics classes. She draws attention to how situations where learners reason, argue, provide explanations, and defend their respective stance generate work on authorial identity. As such, the self as author is translated into classroom practices and students' voices in and about mathematics that go beyond procedural, well-rehearsed school mathematics. These include opportunities to embark on a quest for mathematical meaning making (Boaler 2002), to experience "knowledge ownership" (Hogan 2008, p. 110), and to introduce a paradigm shift in mathematics education that adopts a "knowledge-making epistemology" (Jorgensen 2014, p. 316). Shifting attention to students' voices within mathematics may allow these to be noticed as authorial identity.

\subsection{Socioculturally available selfhoods}

According to Ivanič (1998), possibilities for identities concern "prototypical possibilities for self-hood which are available to [learners] in the social context" (p. 27). Indeed, cultural, historical, and sociological contexts function as repositories of identities one can align with or reject (Bruner 1986; Giddens 1991). Drawing on Ivanič (1998), we understand socioculturally available selfhoods as instances where a learner of mathematics carries out a mathematicsrelated behaviour of a less (or more) privileged status and in turn redefines possibilities of selfhoods for others.

Research in K-12 mathematics education demonstrates how such available identities can be recruited and further reproduced through multiple venues that include cultural or family stories (Sfard and Prusak 2005), the popular media (Mendick 2004), or sociocultural contexts (Nollenberger et al. 2016). Indeed, researchers have continually demonstrated how sociocultural and historical scripted roles dictate and reproduce what one can be, do, or say mathematically (see Betz and Sekaquaptewa 2012). Consider the work of Darragh (2015) who interviewed students as they were transitioning from elementary school to high school and who showed how institutional practices of streaming and privileged ways of doing mathematics "provide a script for performing 'good at mathematics' that works to assist other students in excluding themselves from further mathematics" (p. 100).

Similarly, Radovic et al. (2017) employed diverse tools (eliciting the mathematical autobiographies, positioning of self and others as learners of mathematics, eliciting their authorial voices, and talking about characters they identify with) to explore the mathematical identity of three teenage girls studying in the same class in a high school in Chile "a country where the relationship between girls and mathematics is still seen as problematic" (p. 438). These researchers show how social structures, gender, and class expectations provide performance scripts for the girls as learners of mathematics.

Research that pertains to socioculturally available selfhoods has explored such identities mostly through racialized (see e.g., Berry et al. 2011; Nasir and Hand 2008; Nasir and de Royston 2013) and gendered mathematical identity (see Radovic et al. 2017). Hogan's (2008) conclusion in regard to Nora's (a student) gendered identity that constrained her development as a learner of mathematics is revealing, "In the absence of a culturally relevant, empowering environment, teacher and student have fallen into the default script and performance of gendered identity" (p. 109).

Against this backdrop, it is worth noting the mathematical identities that popular media offer to students for them to accept or reject. For example, Mendick (2004) found that movies perpetuate myths such as that mathematics is gender-specific, and that doing mathematics is "individual, fevered, mysterious, and intuitive" (p. 46). Similarly, Epstein et al. (2010) show how mathematics is represented in popular culture as a "secret language" (p. 45) and mathematicians as staid and imperturbable. Similar ideas are portrayed in other popularized media of mathematicians. Consider, for example, Ramanujan's biography written by Kanigel (1991). Ramanujan is depicted as someone who simply 
knew mathematics and whose mathematical ideas came to him through his family deity Namagiri Thayar. Or consider the recent movie Hidden Figures (Melfi and Schroeder 2016) that, unintentionally or conveniently, portrays mathematics as a gift - that one either has or does not have. While such socioculturally available identities offer very limited and limiting sources for identification for learners of mathematics, other identities such as family or community members who were successful in mathematics may provide positive sources for identification for students to align with (see e.g., Berry et al. 2011; Sfard and Prusak 2005).

The interconnectedness between the dimension of socioculturally available selfhoods and discoursal identity is captured in the research literature (see e.g., Hogan 2008). This interanimation highlights the role of teachers in shaping learners' mathematics identity work (see e.g., Heyd-Metzuyanim and Sfard 2011). In light of this relationship, Picho and Schmader (2018) suggest "student- and teacher-student interactions constitute a large part of the learning environment, and the nature of these interactions could either exacerbate or attenuate [stereotype threat] ST susceptibility among students from marginalized social groups" (p. 304).

Socioculturally available identities can be operationalized through reference, mention, and discussion of widespread beliefs about mathematics and mathematicians that are many times enacted and performed through characters in movies and popular media. Future research that looks more deeply into how these available identities are recruited, aligned with, or rejected can shed more light on how socioculturally available identities shape learners' mathematical identity and inform their autobiographical, discoursal, and authorial mathematics identity.

\section{Discussion}

The purpose of this theory-driven review was to offer a networked framework to conceptualize and operationalize identity within K-12 mathematics education. For this purpose, I imported Ivanič's (1998) four-part model, which provides an instrumental framework that brings together established and emerging research on K-12 identity in mathematics education. In this paper I extended the theoretical principles that underlie each dimension to provide theoretical background to and operational framework for the exploration of each dimension. The overarching focus that guided my reading of the studies was how identity is operationalized in K-12 research on learners' mathematical identity. This focus was used to categorize each study into one of the four dimensions (Table 1).

The categorization of these research studies is not collectively exhaustive nor is it mutually exclusive. Using this four-part model is very much like looking at a rubber band that has patterns on it that are not clearly visible when the rubber band is relaxed. To better understand what each dimension of identity implies, I stretch out the proverbial rubber band to reveal the connecting lines between and among students' past experiences as they are sequenced and interpreted (autobiographical identity), how students talk about themselves and others as learners and doers of mathematics (discoursal identity), how students develop their authorial voice and appropriate knowledge and ideas in and about mathematics (authorial identity), and students' imitation or rejection of available selfhoods (socioculturally available identity).

Zooming in and looking at each dimension at a time allows us to then zoom out to see how these dimensions are connected. Each of the four identity-related dimensions needs to be recognized as part of a larger system that has the potential to allow researchers as well as practitioners to have a view of the creases, wrinkles, and folds of the landscape we call identity. In the face of the negative experiences associated with school mathematics, it is compelling to see how identity work can be harnessed to acts of intervention. As Heyd-Metzuyanim and Sfard (2011) note, "teachers' actions, as well intended as they might, can harm the process of learning by prompting and then fuelling counterproductive identifying interactions" (p. 17). It is by carefully attending to learners' multidimensional identity work that teachers can intervene and work together with learners on their developing identities as learners and doers of mathematics. This is illustrated in Venkat and Graven's (2008) and in McFeetors and Mason's (2005) studies, where a teacher's careful attention to learners' mathematical stories (autobiographical identity) and her guidance to support and sustain positive mathematical identities (discoursal identity and authorial identity) help construct identities of successful learners of mathematics.

The four-part model suggested in this paper informs the use of multiple-method research designs that can be conducive to an investigation of ipse mathematics identity. In addition to use of drawings to elicit learners' beliefs and experiences (see Towers et al. 2018), such research designs and methodologies can include both focus group and oneon-one interviews (see Fellus 2018); conversation over video-recorded classroom situations where students watch video clips of their own or others' classroom interactions and provide interpretations of what they see while at the same time also engaging in identity work (see Mason and McFeetors 2007); elicitation of past experiences through the use of what McAdams (1995) calls life chapters where participants organize their past experiences with mathematics in the form of book chapters and provide interpretations of the relationship between past events, present actions, and future plans (see Fellus 2018); invitation to assign humanlike characteristics to mathematics in order to elicit learners' 
Table 1 Dimensions, definitions, and studies in K-12 mathematics education

\begin{tabular}{|c|c|c|c|}
\hline \multirow[t]{2}{*}{ Dimension } & \multicolumn{2}{|l|}{ Definition } & \multirow[t]{2}{*}{ K-12 Mathematics Identity Studies } \\
\hline & Ivanič's definition & $\begin{array}{l}\text { Complementary Definition from } \\
\text { the Literature }\end{array}$ & \\
\hline Autobiographical Identity & $\begin{array}{l}\text { Stringing together past experi- } \\
\text { ences that forms and informs } \\
\text { attitudes, beliefs, and actions } \\
\text { (Ivanič 1998) }\end{array}$ & $\begin{array}{l}\text { Reconstruction of past events that } \\
\text { impacts the present and shapes } \\
\text { the future as "positive" or "nega- } \\
\text { tive" (McAdams and Bowman } \\
\text { 2001) }\end{array}$ & $\begin{array}{l}\text { Berry et al. } 2011 \\
\text { Di Martino and Zan } 2010 \\
\text { Graven and Buytenhuys } 2010 \\
\text { Lange and Meaney } 2011 \\
\text { Towers et al. } 2018\end{array}$ \\
\hline Discoursal Identity & $\begin{array}{l}\text { By address (how individuals } \\
\text { are talked to by others), and by } \\
\text { attribution (how individuals are } \\
\text { talked to and about by self and } \\
\text { others) (Ivanič 2006) }\end{array}$ & $\begin{array}{l}\text { Stories that "are reifying, endors- } \\
\text { able, and significant" (Sfard and } \\
\text { Prusak 2005, p. 16) }\end{array}$ & $\begin{array}{l}\text { Andersson et al. } 2015 \\
\text { Bishop } 2012 \\
\text { Boaler } 2005 \\
\text { Boaler et al. } 2000 \\
\text { Damarin } 2000 \\
\text { Heyd-Metzuyanim 2013, } 2017 \\
\text { Hogan } 2008 \\
\text { Mason and McFeetors } 2007 \\
\text { Oakes } 1990 \\
\text { Sfard and Prusak } 2005 \\
\text { Wood } 2013\end{array}$ \\
\hline Authorial Identity & $\begin{array}{l}\text { Stating positions, ideas, and } \\
\text { beliefs (Ivanič 1998) }\end{array}$ & $\begin{array}{l}\text { Appropriation of content knowl- } \\
\text { edge, words, and ideas (Bakhtin } \\
\text { 1981) }\end{array}$ & $\begin{array}{l}\text { Black } 2009 \\
\text { Grant et al. } 2015 \\
\text { Landers } 2013 \\
\text { Langer-Osuna 2015, 2016, 2017, } \\
\quad 2018 \\
\text { McFeetors and Mason } 2005 \\
\text { Silver } 1997 \\
\text { Takeuchi } 2018 \\
\text { Venkat and Graven } 2008 \\
\text { Wirtz and Kahn } 1982\end{array}$ \\
\hline $\begin{array}{l}\text { Socioculturally Available Identi- } \\
\text { ties }\end{array}$ & $\begin{array}{l}\text { Prototypical possibilities for } \\
\text { self-hood available in the social } \\
\text { context (Ivanič 1998) }\end{array}$ & $\begin{array}{l}\text { Socioculturally prescribed beliefs } \\
\text { (Mendick 2005) }\end{array}$ & $\begin{array}{l}\text { Ambady et al. } 2001 \\
\text { Berry et al. } 2011 \\
\text { Betz and Sekaquaptewa } 2012 \\
\text { Black et al. } 2010 \\
\text { Cvencek } 2011 \\
\text { Darragh } 2015 \\
\text { Epstein et al. } 2010 \\
\text { Hogan and Marks } 2009 \\
\text { Langer-Osuna } 2011 \\
\text { Mendick 2004, } 2005 \\
\text { Nasir and Hand } 2008 \\
\text { Nasir and de Royston } 2013 \\
\text { Picho and Schmader } 2018 \\
\text { Radovic et al. } 2017 \\
\text { Stinson } 2009\end{array}$ \\
\hline
\end{tabular}

relationships with mathematics, as Zazkis (2015) did in asking his prospective mathematics teachers to describe their relationship with mathematics as if it were a human being; use of metaphors in thinking about mathematics as Markovits and Forgasz (2017) did, asking young children to think about animal metaphors to express their thoughts about mathematics; harnessing the method of duoethnography, which builds on a collective sense making over mathematics-related issue through interaction among two (thus duo) or more participants as Zazkis and Koichu (2015) did in their conversation on understanding the infinitude of primes; capturing visual representations through photographs and videos-also known as photovoice-of thoughts about mathematics to allow for students' voices to be heard as they express ideas in and about mathematics thus developing their mathematics authorial identity (see Harkness and Stallworth 2013); and writing short mathematics-related poems that are instrumental for their structural and expressive simplicity as Haltiwanger and Simpson (2013) illustrate through examples of students' cinquains (five-line poems) on mathematical concepts. 


\section{Conclusion}

I imported Ivanič's (1998) theoretical framework into mathematics education to suggest a form of investigation that pulls four identity-related dimensions together at once. The framework was then used to conduct a theorydriven review of K-12 identity-related research literature. This theory-driven review shows how the four dimensions, while closely related, are not subsets of each other. While each stands in its own right, which may explicate the tendency to explore them as stand-alone identity aspects, they cannot-and should not-be treated separately or studied in isolation but rather as a networked system that is premised on and subject to interanimated relationships. As such, each necessitates a definition both conceptual and operational. This framework is useful because it has the potential to treat identity as a neural network, which highlights the nonlinear interconnectedness between the different dimensions and, in turn, unblurs the lines of distinction between the different dimensions.

Learners' identity that is epistemologically understood as how one can become and ontologically perceived as multifarious stories, opens space for teachers to listen and be sensitive to learners' discoursal identity through address and attribution, their acts of alignment with socioculturally available selfhoods, their interpretation and reinterpretation of past experiences, and their developing an authorial self where they receive what Bourdieu (1991) calls the skeptron that references the right to speak and the right to be heard. The challenge will most probably be to harness identity work intentionally to what schools are for, and to bring educational change that allows all to attain mathematically. Educational systems where identities are, more often than not, institutionally assigned (see Boaler 2005; Boaler et al. 2000; Mason and McFeetors 2007; Oakes 1990), and contexts where identities are socioculturally disseminated (see Epstein et al. 2010) need to provide better support to learners by recognizing their developing identities as simultaneously multi-dimensional. Seriously, and carefully, attending to learners' four-part identity network can rigorously demonstrate how identity work forms and informs learners' future trajectories as learners of mathematics.

Open Access This article is distributed under the terms of the Creative Commons Attribution 4.0 International License (http://creativeco mmons.org/licenses/by/4.0/), which permits unrestricted use, distribution, and reproduction in any medium, provided you give appropriate credit to the original author(s) and the source, provide a link to the Creative Commons license, and indicate if changes were made.

\section{References}

Ambady, N., Shih, M., Kim, A., \& Pittinsky, T. L. (2001). Stereotype susceptibility in children: Effects of identity activation on quantitative performance. Psychological Science, 12(5), 385-390.

Andersson, A., Valero, P., \& Meaney, T. (2015). I am [not always] a maths hater": Shifting students' identity narratives in context. Educational Studies in Mathematics, 90(2), 143-161.

Bakhtin, M. (1981). The dialogic imagination (C. Emerson \& M. Holquist, Trans.). Austin: University of Texas Press.

Berry, R. Q., Thunder, K., \& McClain, O. L. (2011). Counter narratives: Examining the mathematics and racial identities of black boys who are successful with school mathematics. Journal of African American Males in Education, 2(1), 10-23.

Betz, D. E., \& Sekaquaptewa, D. (2012). My fair physicist? Feminine math and science role models demotivate young girls. Social Psychological and Personality Science, 3(6), 738-746.

Bishop, J. P. (2012). "She's always been the smart one. I've always been the dumb one": Identities in the mathematics classroom. Journal for Research in Mathematics Education, 43(1), 34-74.

Black, L. (2009). Differential participation in whole-class discussions and the construction of marginalised identities. The Journal of Educational Enquiry, 5(1), 34-54.

Black, L., Williams, J., Hernandez-Martinez, P., Davis, P., Pampaka, M., \& Wake, G. (2010). Developing a 'leading identity': The relationship between students' mathematical identities and their career and higher education aspirations. Educational Studies in Mathematics, 73(1), 55-72.

Boaler, J. (2002). The development of disciplinary relationships: Knowledge, practice, and identity in mathematics classrooms. For the Learning of Mathematics, 22(1), 42-47.

Boaler, J. (2005). The 'Psychological Prison' from which they never escaped: The role of ability grouping in reproducing social class inequalities. FORUM, 47(2-3), 135-144.

Boaler, J., Wiliam, D., \& Brown, M. L. (2000). Students' experiences of ability grouping-disaffection, polarisation and the construction of failure. British Educational Research Journal, 26(5), 631-648.

Bourdieu, P. (1991). Language and symbolic power (G. Raymond \& M. Adamson, Trans.). Cambridge: Harvard University Press.

Bruner, J. (1986). Actual minds, possible worlds (The JerusalemHarvard Lectures). Cambridge: Harvard University Press.

Cvencek, D., Meltzoff, A. N., \& Greenwald, A. G. (2011). Math-gender stereotypes in elementary school children. Child Development, 82(3), 766-779.

Damarin, S. (2000). The mathematically able as marked category. Gender and Education, 12(1), 69-85.

Darragh, L. (2015). Recognising 'good at mathematics': Using a performative lens for identity. Mathematics Education Research Journal, 27(1), 83-102.

Darragh, L. (2016). Identity research in mathematics education. Educational Studies in Mathematics, 93(1), 19-33.

Di Martino, P., \& Zan, R. (2010). 'Me and maths': Towards a definition of attitude grounded on students' narratives. Journal of Mathematics Teacher Education, 13(1), 27-48.

Epstein, D., Mendick, H., \& Moreau, M.P. (2010). Imagining the mathematician: Young people talking about popular representations of maths. Discourse: Studies in the Cultural Politics of Education, 31(1), 45-60.

Erdinast-Vulcan, D. (2008). The I that tells itself: A Bakhtinian perspective on narrative identity. Narrative, 16(1), 1-15.

Fellus, O. (2018). Teenagers at a crossroad: Exploring newcomer teenagers' identity as learners of mathematics and English as an additional language (Unpublished doctoral dissertation). University of Ottawa, Ottawa, Ontario. 
Fellus, O., \& Biton, Y. (2017). One is not born a mathematician: In conversation with Vasily Davydov. International Journal for Mathematics Teaching and Learning, 18(2), 136-160. http:// www.cimt.org.uk/ijmtl/index.php/IJMTL/article/view/88.

Fellus, O., \& Biton, Y. (2018). Putting the horses before the cart: Technology, creativity, and authorship harnessed three abreast. In V. Freiman \& J. Tassel (Eds.), Creativity and technology in mathematics education: Mathematics Education in the digital era (Vol. 10, pp. 507-529). Cham, Switzerland: Springer.

Fellus, O., \& Glanfield, F. (2019). What makes a mathematician? For the Learning of Mathematics, 39(1), 26-27.

Feynman, R. P. (1965). New textbooks for the "new" mathematics. Engineering and Science, 28(6), 9-15.

Gergen, K. J. (1991). The saturated self: Dilemmas of identity in contemporary life. New York: Basic.

Giddens, A. (1991). Modernity and self-identity: Self and society in the late modern age. Cambridge: Polity Press.

Grant, M. R., Crompton, H., \& Ford, D. J. (2015). Black male students and the Algebra Project: Mathematics identity as participation. Journal of Urban Mathematics Education, 8(2), 87-118.

Graven, M., \& Buytenhuys, E. (2010). Mathematical literacy in South Africa: Increasing access and quality in learners' mathematical participation both in and beyond the classroom. In B. Atweh, M. Graven, W. Secada, \& P. Valero (Eds.), Mapping equity and quality in mathematics education (pp. 493-509). Heidelberg: Springer.

Haltiwanger, L., \& Simpson, A. M. (2013). Beyond the write answer: Mathematical connections. Mathematics Teaching in the Middle School, 18(8), 492-498.

Harkness, S. S., \& Stallworth, J. (2013). Photovoice: Understanding high school females' conceptions of mathematics and learning mathematics. Educational Studies in Mathematics, 84(3), 329-347.

Harré, R., \& Gillett, G. (1994). The discursive mind. CA: Sage Publications.

Heyd-Metzuyanim, E. (2013). The co-construction of learning difficulties in mathematics-Teacher-student interactions and their role in the development of a disabled mathematical identity. Educational Studies in Mathematics, 83(3), 341-368.

Heyd-Metzuyanim, E. (2017). Identity as a nexus of affect and discourse in mathematical learning. For the Learning of Mathematics, 37(3), 33-38.

Heyd-Metzuyanim, E., \& Sfard, A. (2011). Identity struggles in the mathematics classroom: On learning mathematics as an interplay of mathematizing and identifying. International Journal of Educational Research, 51-52, 128.s-145.s.

Hodgen, J., \& Marks, R. (2009). Mathematical 'ability' and identity: A sociocultural perspective on assessment and selection. In L. Black, H. Mendick, \& Y. Solomon (Eds.), Mathematical relationships in education: Identities and participation (pp. 31-42). Abingdon: Routledge.

Hogan, M. P. (2008). The tale of two Noras: How a Yup'ik middle schooler was differently constructed as a math learner. Diaspora, Indigenous, and Minority Education, 2(2), 90-114.

Holland, D., Lachicotte, W., Skinner, D., \& Cain, C. (1998). Identity and agency in cultural worlds. Cambridge, MA: Harvard University Press.

Ivanič, R. (1998). Writing and identity: The discoursal construction of identity in academic writing. Amsterdam: John Benjamins.

Ivanič, R. (2006). Language, learning, and identification. In R. Kiely, P. Rea Dickens, H. Woodfield, and G. Clibbon (Eds.), Language, culture and identity in applied linguistics, (pp. 7-29). London: British Association of Applied Linguistics and Equinox.

Jorgensen, R. (2014). Social theories of learning: A need for a new paradigm in mathematics education. In J. Anderson, M. Cavanagh, \& A. Prescott. (Eds.), Curriculum in focus: Research guided practice (Proceedings of the 37th annual conference of the Mathematics
Education Research Group of Australasia, pp. 311-318). Sydney: MERGA.

Kanigel, R. (1991). The man who knew infinity: A life of the genius Ramanujan. New York: Scribner.

Klein, E. (1967). A comprehensive etymological dictionary of the English language. New York: Elsevier Scientific Publishing Company.

Landers, M. (2013). Buying in and checking out: Identity development and meaning making in the practice of mathematics homework. Qualitative Research in Education, 2(2), 130-160.

Lange, T., \& Meaney, T. (2011). I actually started to scream: Emotional and mathematical trauma from doing school mathematics homework. Educational Studies in Mathematics, 77(1), 35-51.

Langer-Osuna, J. M. (2011). How Brianna became bossy and Kofi came out smart: Understanding the trajectories of identity and engagement for two group leaders in a project-based mathematics classroom. Canadian Journal of Science, Mathematics and Technology Education, 11(3), 207-225.

Langer-Osuna, J. (2015). From getting "fired" to becoming a collaborator: A case on student autonomy and the co-construction of identity and engagement in a project-based mathematics classroom. Journal of the Learning Sciences, 24(1), 53-92.

Langer-Osuna, J. M. (2016). The social construction of authority among peers and its implications for collaborative mathematics problem solving. Mathematical Thinking and Learning, 18(2), 107-124.

Langer-Osuna, J. M. (2017). Authority, identity, and collaborative mathematics. Journal for Research in Mathematics Education, 48(3), 237-247.

Langer-Osuna, J. M. (2018). Exploring the central role of student authority relations in collaborative mathematics. ZDM Mathematics Education, 50(6), 1077-1087.

Mann, E. L. (2006). Creativity: The essence of mathematics. Journal for the Education of the Gifted, 30(2), 236-260.

Markovits, Z., \& Forgasz, H. (2017). "Mathematics is like a lion": Elementary students' beliefs about mathematics. Educational Studies in Mathematics, 96(1), 49-64.

Mason, R., \& McFeetors, J. (2007). Student trajectories in high school mathematics: Issues of choice, support, and identitymaking. Canadian Journal of Science, Mathematics, and Technology Education, 7(4), 291-316.

McAdams, D. P. (1995). The life story interview. Retrieved August 23, 2002, from http://www.urbanlab.org/articles/McAda ms_2008_LifeStoryInterview.pdf.

McAdams, D. P., \& Olson, B. D. (2010). Personality development: Continuity and change over the life course. Annual Review of Psychology, 61, 517-542.

McFeetors, P. J., \& Mason, R. T. (2005). Voice and success in nonacademic mathematics courses: (Re)forming identity. For the Learning of Mathematics., 25(3), 16-23.

Melfi, T., \& Schroeder, A. (Writer), \& Melfi, T. (Producer). (2016). Hidden Figures [Motion picture]. U.S.A: $20^{\text {th }}$ Century Fox.

Mendick, H. (2004). A mathematician goes to the movies. Proceedings of the British Society for Research into Learning Mathematics, 24(1), 43-48.

Mendick, H. (2005). A beautiful myth? The gendering of being/ doing 'good at maths'. Gender and Education, 17(2), 203-219.

Nasir, N. I. S., \& de Royston, M. M. (2013). Power, identity, and mathematical practices outside and inside school. Journal for Research in Mathematics Education, 44(1), 264-287.

Nasir, N. I. S., \& Hand, V. (2008). From the court to the classroom: Opportunities for engagement, learning, and identity in basketball and classroom mathematics. The Journal of the Learning Sciences, 17(2), 143-179.

NCTM. (2000). Principles and standards for school mathematics. Reston, VA: National Council of Teachers of Mathematics. 
Nollenberger, N., Rodríguez-Planas, N., \& Sevilla, A. (2016). The math gender gap: The role of culture. The American Economic Review, 106(5), 257-261.

Oakes, J. (1990). Multiplying inequalities: The effects of race, social class, and tracking on opportunities to learn mathematics and science. Santa Monica, CA: The RAND Corporation.

Ochs, E., \& Capps, L. (1996). Narrating the self. Annual Review of Anthropology, 25, 19-43.

Picho, K., \& Schmader, T. (2018). When do gender stereotypes impair math performance? A study of stereotype threat among Ugandan adolescents. Sex Roles, 78(3-4), 295-306.

Polkinghorne, D. E. (1988). Narrative knowing and the human sciences. Suny Press.

Radovic, D., Black, L., Salas, C. E., \& Williams, J. (2017). Being a girl mathematician: Diversity of positive mathematical identities in a secondary classroom. Journal for Research in Mathematics Education, 48(4), 434-464.

Radovic, D., Black, L., Williams, J., \& Salas, C. E. (2018). Towards conceptual coherence in the research on mathematics learner identity: A systematic review of the literature. Educational Studies in Mathematics, 99(1), 21-42.

Ricoeur, P. (1992). Oneself as another. Chicago: University of Chicago Press.

Sfard, A., \& Prusak, A. (2005). Telling identities: In search of an analytic tool for investigating learning as a culturally shaped activity. Educational Researcher, 34(4), 14-22.

Silver, E. A. (1997). Fostering creativity through instruction rich in mathematical problem solving and problem posing. ZDM Mathematics Education, 29(3), 75-80.

Stinson, D. (2009). Negotiating sociocultural discourses: The counterstorytelling of academically and mathematically successful African American male students. In D. B. Martin (Ed.), Mathematics teaching, learning, and liberation in the lives of Black children (pp. 265-288). New York: Routledge.

Takeuchi, M. A. (2018). Power and identity in immigrant parents' involvement in early years mathematics learning. Educational Studies in Mathematics, 97(1), 39-53.
Towers, J., Hall, J., Rapke, T., Martin, L. C., \& Andrews, H. (2016). Autobiographical accounts of students' experiences learning mathematics: A review. Canadian Journal of Science, Mathematics and Technology Education, 17(3), 152-164.

Towers, J., Takeuchi, M. A., \& Martin, L. C. (2018). Examining contextual influences on students' emotional relationships with mathematics in the early years. Research in Mathematics Education, 20(2), 146-165.

Venkat, H., \& Graven, M. (2008). Opening up spaces for learning: Learners' perceptions of Mathematical Literacy in Grade 10. Education as Change, 12(1), 29-44.

Vygotsky, L. S. (1978). Mind in society: The development of higher psychological processes. Cambidge: Harvard university press.

Wenger, E. (1998). Communities of practice: Learning, meaning, and identity. New York: Cambridge University Press.

Wirtz, R. W., \& Kahn, E. (1982). Another look at applications in elementary school mathematics. The Arithmetic Teacher, 30(1), $21-25$.

Wood, M. B. (2013). Mathematical micro-identities: Moment-tomoment positioning and learning in a fourth-grade classroom. Journal for Research in Mathematics Education, 44(5), 775-808.

Zazkis, D. (2015). Monsters, lovers, and former friends: Exploring relationships with mathematics via personification. For the Learning of Mathematics, 35(1), 33-38.

Zazkis, R., \& Koichu, B. (2015). A fictional dialogue on infinitude of primes: Introducing virtual duoethnography. Educational Studies in Mathematics, 88(2), 163-181.

Publisher's Note Springer Nature remains neutral with regard to jurisdictional claims in published maps and institutional affiliations. 